\title{
Functional Characterization of the Keratinocyte Growth Factor System in Human Fetal Gastrointestinal Tract
}

\author{
PIERRE CHAILLER, JEAN-RENÉ BASQUE, LINA CORRIVEAU, AND DANIEL MÉNARD
}

MRC Group on the Functional Development and Physiopathology of the Digestive Tract, Department of Anatomy and Cell Biology, Faculty of Medicine, Université de Sherbrooke, Sherbrooke, Québec, Canada

\begin{abstract}
ABS
Keratinocyte growth factor (KGF) is a paracrine growth
factor whose mRNA has been detected in human adult and
rodent gut tissues together with its associated receptor. Our
objectives were to assess the presence of immunoreactive KGF
ligand and receptor proteins in human fetal gastrointestinal (GI)
tract segments and to evaluate the role of exogenous KGF on cell
proliferation and intestinal digestive functions. KGF (26-28 kD
doublet) was identified in esophagus, stomach, small intestine,
and colon by Western blot. Its receptor (135 kD) was ubiqui-
tously detected in proliferative and differentiated epithelial cells
of each GI segment by use of indirect immunofluorescence
(anti-bek, anti-K-sam). The addition of KGF to explants cultured
in serum-free conditions greatly stimulated DNA synthesis in all GI tract tissues. The growth factor up-regulated intestinal su-
\end{abstract}

crase-isomaltase and $\gamma$-glutamyl-transpeptidase activities in jejunal explants, whereas it down-regulated these activities in colon explants. It is suggested that the KGF system likely represents an important paracrine pathway that is able to stimulate cell proliferation in all segments of the human fetal GI tract and to differentially regulate intestinal digestive functions. (Pediatr Res 48: 504-510, 2000)

\section{Abbreviations}

KGF, keratinocyte growth factor

FGF, fibroblast growth factor

KGF-R, KGF receptor

GI, gastrointestinal (tract, tissues)

SI, sucrase-isomaltase.
KGF or FGF-7 is a member of the heparin-binding growth factor family [reviewed by Baird and Klagsbrun (1)]. This growth factor is able to stimulate the proliferation of epithelial cells and to positively influence their polarization/differentiation status in culture (2-4). Its associated receptor (KGF-R) is virtually identical to the K-sam protein found in KATO-III cells and gastric carcinomas $(5,6)$, which is the product of an alternative transcript of the FGFR-2/bek gene. Splicing of the mRNA alters a small region of the extracellular domain of the receptor and confers increased capacity for KGF binding (7). One study (8) clearly demonstrated that the bek gene is expressed in great amounts in diverse epithelia (skin, intestine, stomach, kidney) of the mouse embryo and that the alternative transcript encoding the KGF-R represents the major form found in these tissues. Some other important features characterize this growth factor: 1) KGF is exclusively synthesized by

Received December 22, 1999; accepted May 8, 2000

Correspondence and reprint requests: Daniel Ménard, Ph.D., Département d'anatomie et de biologie cellulaire, Faculté de Médecine, Université de Sherbrooke 3001, 12e Ave. N., Sherbrooke, Québec, Canada J1H 5N4.

Supported by a grant from the Medical Research Council (MRC) of Canada (D.M.).

Results were presented at the 1999 Pan-American Digestive Disease Week, Vancouver, British Columbia, and were published in abstract form in Can J Gastroenterol 13(suppl B):225B, July/August 1999 . mesenchymal cells and exerts its action on epithelial cells (9, 10) via KGF-R, and 2) as opposed to other growth factor receptors [epidermal growth factor/transforming growth factor (EGF/TGF $\alpha$ ), hepatocyte growth factor (HGF), insulin-like growth factor (IGF) associated with basolateral membranes of epithelial cells, KGF-R is also present in the cytoplasm (6).

During the last years, attention has been focused on the possible implication of this paracrine growth factor in the regulation of GI physiology. Indeed, the observations that KGF and KGF-R mRNA are present in all segments of the adult rat GI tract and hepatocytes (11) as well as in fetal rat stomach (12) supported the concept that the KGF system could be involved in normal development and maintenance of digestive organs. When administered parenterally to adult animals, KGF increases wet weight of intestine and stomach, exerts a positive influence on stem cell proliferation from the foregut to the colon, and causes a dramatic increase of cholesterol and triglyceride circulating levels $(11,13)$. Some of these results were confirmed using rabbit gastric epithelial monolayers in which KGF stimulates cell proliferation and migration by itself or in combination with other mitogens (14). Another study (15) demonstrated that KGF-induced hypertriglyceridemia results mainly from stimulation of hepatic lipolysis. Thus, it has been 
hypothesized that this growth factor could play a dual role in the context of digestive physiology in the rat; it may act as a trophic growth factor as well as a regulator of secretory/ catabolic activity.

Recent studies $(16,17)$ reported that the mRNA for KGF and its receptor are detected in the adult human intestine and that their expressions are positively modulated in patients suffering from inflammatory bowel diseases. Also, upregulation of the KGF-R seems to be biologically significant in the context of tumorigenesis as it is related to the appearance of aggressive gastric and esophageal carcinomas $(5,6,18)$. Nonetheless, the ontogenic expression of KGF and KGF-R in human GI segments, as well as their potential roles, has yet to be characterized. One has to keep in mind that many segments of the human fetal GI tract acquire their adult morphologic and functional characteristics very early (10 to $15 \mathrm{wk}$ of gestation) as opposed to rodents $(19,20)$. Furthermore, our ability to maintain these different fetal segments in serum-free organ culture (21-24) allows us to specifically characterize the modulators involved in the regulation of human GI functions. The objectives of the current study were the following: 1) to verify the presence of KGF and KGF-R proteins in human fetal esophagus, stomach, small intestine, and colon by Western blot analysis, 2) to localize putative KGF-R at the cellular level by use of immunohistochemistry (with anti-bek, anti-K-sam), and 3 ) to assess the specific effects of exogenous recombinant KGF on GI tissues maintained in organ culture. Our results suggest that the KGF system likely represents an important paracrine pathway that stimulates epithelial cell proliferation in all segments of the human fetal GI tract and that also modulates intestinal digestive functions.

\section{METHODS}

Collection of specimens. GI tissues from 35 fetuses varying in age from 16 to $20 \mathrm{wk}$ postfertilization [fetal ages were estimated according to Streeter (25)] were obtained from normal elective pregnancy terminations. Studies were approved by the Institutional Human Subject Review Board, and no tissue was collected from cases associated with known fetal abnormality or death. Digestive organs were immersed in Leibovitz L-15 medium (GIBCO-BRL Life Technologies, Burlington, Ontario, Canada) containing gentamicin and nystatin $(40 \mu \mathrm{g} /$ $\mathrm{mL}$ ) and prepared for culture within $30 \mathrm{~min}$. For immunofluorescence studies, specimens were rinsed with medium, directly embedded in OCT (Optimum Cutting Temperature embedded compound; Tissue Tek, Miles Laboratories, Elkhart, IN, U.S.A.), and frozen in liquid nitrogen.

Organ culture. The esophagus was deposited on sterile agar, split longitudinally, and dissected into explants $\left(3 \times 7 \mathrm{~mm}^{2}\right)$ (21). Whole stomach was cut along the great curvature; its cardiac and antral portions were excised leaving the representative glandular stomach (fundus/corpus) that was cut into explants $\left(5 \times 5 \mathrm{~mm}^{2}\right)(22)$. The jejunum (23) and colon (24) were cleansed of soft tissues (mesentery) and dissected into $5 \times 5-\mathrm{mm}^{2}$ pieces. Explants were then deposited on a lens paper lying on a metal grid in a Falcon organ culture dish (Falcon Plastics, Los Angeles, CA, U.S.A.) and maintained at the interface of medium and atmosphere consisting of 5\% $\mathrm{CO}_{2}: 95 \%$ air and saturated water vapor at $37^{\circ} \mathrm{C}$. Tissues were cultured in serum-free Leibovitz L-15 medium supplemented with gentamicin and nystatin with no additives (controls) or in the presence of $10-50 \mathrm{ng} / \mathrm{mL}$ KGF (PeproTech, Rocky Hill, NJ, U.S.A.). Culture medium was renewed after $24 \mathrm{~h}$ and every $2 \mathrm{~d}$ thereafter. In a single experiment, between 15-20 explants were pooled for each condition to perform biochemical determinations (DNA synthesis, enzymatic activity). For comparative purposes, HGF (Calbiochem, La Jolla, CA, U.S.A.) was also added at 3,10, $20 \mathrm{ng} / \mathrm{mL}$ to jejunal and colonic explants. The dosages used in this study were proven to stimulate proliferation and migration of gastric epithelial cells in primary culture (14).

Determination of DNA synthesis rates. To evaluate the incorporation of thymidine into DNA, $2 \mu \mathrm{Ci}$ of [methyl$\left.{ }^{3} \mathrm{H}\right]$ thymidine $(82.0 \mathrm{Ci} / \mathrm{mmol}$; Amersham Canada, Oakville, Ontario, Canada) was added per milliliter of L-15 medium during the last $6 \mathrm{~h}$ of culture. Explants were pooled and homogenized into ice-cold redistilled water, and the level of radioactive precursor incorporated into trichloroacetic acidprecipitable nuclear material was determined by counting a 0.5 -mL sample (23) in a Beckman liquid scintillation system (Beckman Instruments Inc., Fullerton, CA, U.S.A.). DNA content was determined with calf thymus DNA as standard according to Giles and Myers (26). Data were expressed as $\mathrm{dpm} / \mathrm{mg}$ tissue and reported in stimulation or inhibition percentage versus control value.

Determination of brush-border hydrolase activities. The homogenates were used immediately for enzymatic determinations. Disaccharidases, namely SI and lactase, were assayed according to Dahlqvist as modified by Lloyd and Whelan (27). Alkaline phosphatase (ALPase) and $\gamma$-glutamyl transpeptidase ( $\gamma$-GTase) activities were measured by the methods of Eichholz (28) and Naftalin et al. (29), respectively. Protein content of the homogenates was determined with Folin reagent (30) with use of BSA as a standard (fraction V purchased from Sigma Chemical Co., St. Louis, MO, U.S.A.). Data were expressed in international units $(\mu \mathrm{mol} / \mathrm{min}$ of substrate hydrolyzed) per gram of protein and reported in stimulation or inhibition percentage versus control value.

Gel electrophoresis and immunoblotting. SDS-PAGE was performed as described previously for fetal stomach (31). SDS concentrations of 10 and $12 \%$, respectively, were used to reveal KGF and KGF-R proteins in different segments of the human fetal gut (esophagus, stomach, small intestine, and colon at 14 and $20 \mathrm{wk}$ ). Briefly, total proteins from tissue homogenized in $20 \mathrm{mmol} / \mathrm{L}$ Tris- $\mathrm{HCl} \mathrm{pH} 6.8$ were rapidly processed for solubilization under reducing conditions $(2 \%$ $\beta$-mercaptoethanol), loaded at an 80-100 $\mu \mathrm{g} /$ well concentration, transferred to Trans-Blot nitrocellulose membranes (BioRad, Mississauga, Ontario, Canada), and then processed with the Western-Light Plus Chemiluminescent Detection System (Tropix Inc., Bedford, MA, U.S.A.). A goat polyclonal antihuman KGF (1:1000; Santa Cruz Laboratories, Santa Cruz, CA, U.S.A.), a rabbit polyclonal anti-human bek (1:750; Santa Cruz), a rabbit polyclonal anti-human K-sam (1:750; a kind gift from Dr. M. Terada, National Cancer Center Research 
Institute, Tokyo, Japan), and a mouse monoclonal antikeratin-18 clone CY-90 (1:5000; Sigma Chemical Co.) were tested as primary antibodies. Membranes were incubated with biotinylated secondary antibodies, e.g. rabbit anti-goat $\operatorname{IgG}$ (1:5000), goat anti-rabbit $\operatorname{IgG}(1: 5000)$, or goat anti-mouse IgG $(1: 40,000)$, and then with ALPase-conjugated streptavidin $(1: 20,000)$. Proteins were revealed with ultra-pure CSPD chemiluminescent substrate (Tropix, Bedford, MA, U.S.A.).

Indirect immunofluorescence. Immunohistochemistry was performed on cryosections of GI segments fixed in acetone:chloroform (1:1) for $5 \mathrm{~min}$ at $4^{\circ} \mathrm{C}$ as described (31). After reduction of nonspecific binding (15 min), sections were incubated for $1 \mathrm{~h}$ with anti-bek receptor or anti-K-sam receptor diluted in $0.2 \%$ BSA-PBS (1:30 and 1:100, respectively). FITC-conjugated anti-rabbit IgG (Boehringer Mannheim Canada, Laval, Québec, Canada) was then added for $1 \mathrm{~h}$ at a working dilution of 1:30. Extensive washings with PBS were performed between each of the previous steps. Sections were finally counterstained with $0.01 \%$ Evan blue in PBS, mounted in glycerol:PBS (9:1) containing $0.1 \%$ paraphenylenediamine, and observed with a Reichert Polyvar 2 microscope (Leica Canada, Saint-Laurent, Québec, Canada) equipped for epifluorescence. Photographs were taken with Kodak Tri-X Pan (400 ASA) film. Nonspecific immunostaining was evaluated by omitting the primary antibodies or by replacing them with nonimmune serum.

Statistical analysis. Final results were expressed as mean \pm SEM for biochemical parameters. Statistical significance was fixed at 95\% and evaluated by ANOVA followed by $t$ test when significance was indicated.

\section{RESULTS}

Identification of KGF and its receptor by Western blotting. The presence of immunoreactive KGF and KGF-R proteins was ascertained in 16- to 20-wk GI tract segments by using polyclonal antibodies under reducing conditions (Fig. 1), and equal protein loading was routinely verified by anti-keratin-18 staining. As shown in a representative experiment revealing a 26-28 kD doublet in tissues from a 20-wk-old specimen (Fig. $1 A$ ), KGF was successfully detected in all segments. The minor $145-\mathrm{kD}$ and the major $135-\mathrm{kD}$ forms of FGFR2/bek receptor were visualized in esophagus, stomach, jejunum, and colon by use of an anti-bek antibody. The low molecular-weight receptor of $135 \mathrm{kD}$ (the epithelial spliced variant) was specifically detected with anti-K-sam (Fig. 1B) in all GI tract segments.

Immunofluorescent staining of receptors. KGF-R was localized on tissue cryosections by use of anti-bek and was found to be ubiquitously expressed in the mucosal epithelium of all GI tract segments. No significant staining was visualized in control experiments when omitting the primary antibody or replacing it with rabbit nonimmune serum. In esophagus, stem cells of the basal epithelial layer were intensely reactive, as illustrated in a 20 -wk-old specimen (Fig. 2A), and the suprabasal cells were weakly stained. In stomach, immunoreactivity was associated with basolateral plasma membrane and cytoplasm in both surface and glandular epithelial cells, including those located in the gastric proliferative compartment (Fig.
$\mathbf{A}$

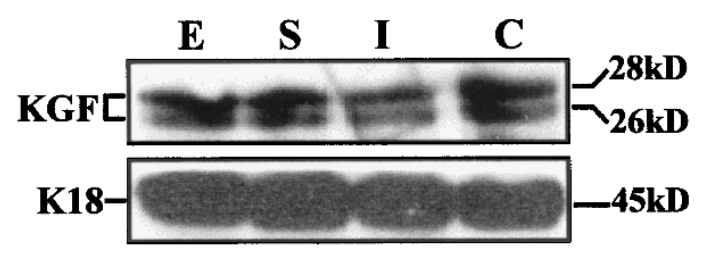

B

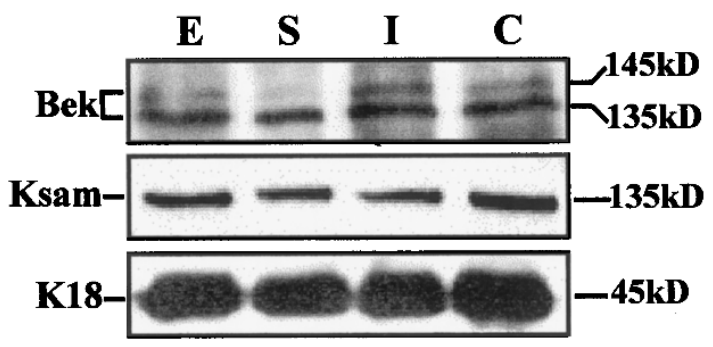

Figure 1. Western blot detection of $\mathrm{KGF}(A)$ and KGF receptors $(B)$ in human fetal GI segments (20 wk of gestation). KGF appeared as a $26-28-\mathrm{kD}$ doublet in all tissues. Two receptor proteins (135 and $145 \mathrm{kD}$ ) encoded by the FGFR-2 gene were revealed with anti-bek (upper panel in $B$ ). The major low molecular-weight receptor was specifically recognized by anti-K-sam (lower panel in $B) . E$ indicates esophagus; $S$, stomach; $I$, intestine (jejunum); $C$, colon; $K 18$, keratin-18 controls. Data shown are representative of three different experiments.

$2 B$ ). A nuclear labeling was also detected in glandular cells. In small intestinal segments (i.e. in duodenum, jejunum, and proximal ileum), KGF-R staining was found at the basolateral membrane and cytoplasm in differentiated enterocytes as well as in crypt cells, and an increasing gradient of expression was clearly established toward apex of the crypt-villus axis (Fig. $2 C)$. The brush border was always negative. In fetal colon, all epithelial cells lining the villi and crypts were labeled (Fig. 2E) as in the small intestine. The use of an anti-K-sam polyclonal antibody yielded similar results; immunostaining was clearly concentrated in digestive epithelia, and its segment-specific patterns were comparable to those obtained with anti-bek (data from jejunum and colon are shown; Fig. 2, $D$ and $F$ ).

KGF and DNA synthesis. The incorporation of $\left[{ }^{3} \mathrm{H}\right]$ thymidine into cellular DNA was determined in control and KGFtreated explants after a 6-h pulse performed at the end of selected culture intervals (Fig. 3). After $2 \mathrm{~d}$ of culture, DNA synthesis was not significantly altered by KGF in any of the GI segments but was dose-dependently increased after $5 \mathrm{~d}$. The highest stimulations were obtained with $50 \mathrm{ng} / \mathrm{mL} \mathrm{KGF}$ in esophagus (40\%) and stomach (41\%). Significant increases were induced at the same concentration in colon (34\%) and jejunum (26\%). Within the age group tested (16 to $20 \mathrm{wk}$ ), no evident correlation was noted between the amplitude of KGF response and fetal age in each segment (not shown).

KGF and intestinal hydrolase activities. The specific activities of SI, lactase, $\gamma$-GTase, and ALPase were measured in cultured explants from 16-20-wk jejunum and colon maintained with or without $\mathrm{KGF}(10,50 \mathrm{ng} / \mathrm{mL})$ (Fig. 4). As 

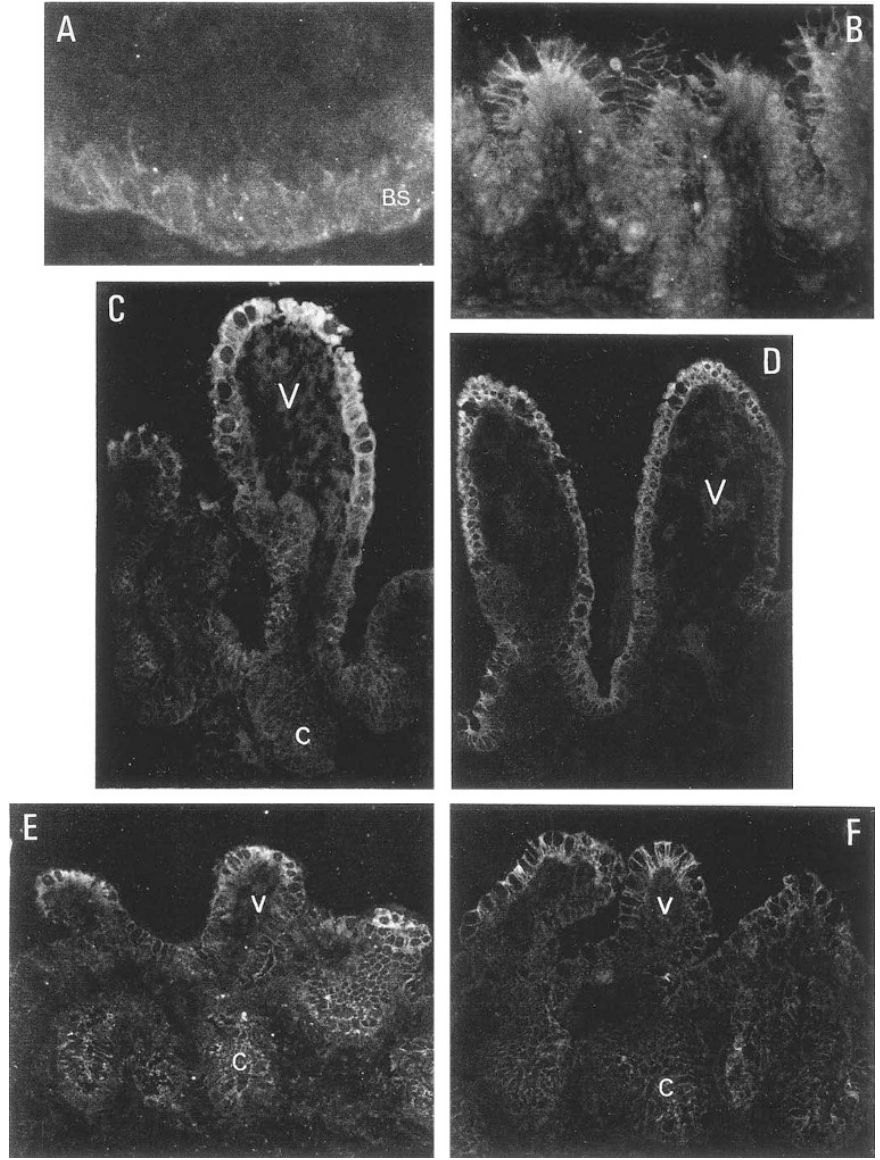

Figure 2. Immunolocalization of KGF-R with anti-bek and anti-K-sam in human fetal GI segments. Anti-bek immunostaining revealed the receptor at level of epithelium in esophagus $(A, 19 \mathrm{wk}, \times 350)$, stomach $(B, 18 \mathrm{wk}, \times 110)$, jejunum $(C, 16 \mathrm{wk}, \times 110)$, and colon $(E, 20 \mathrm{wk}, \times 75)$. Anti-K-sam staining gave similar results; jejunum $(D, 17 \mathrm{wk}, \times 75)$ and colon $(F, 18 \mathrm{wk}, \times 75)$ are illustrated. $B S$ indicates basal stratum (esophageal stem cells); $V$, villus; $C$, crypt.

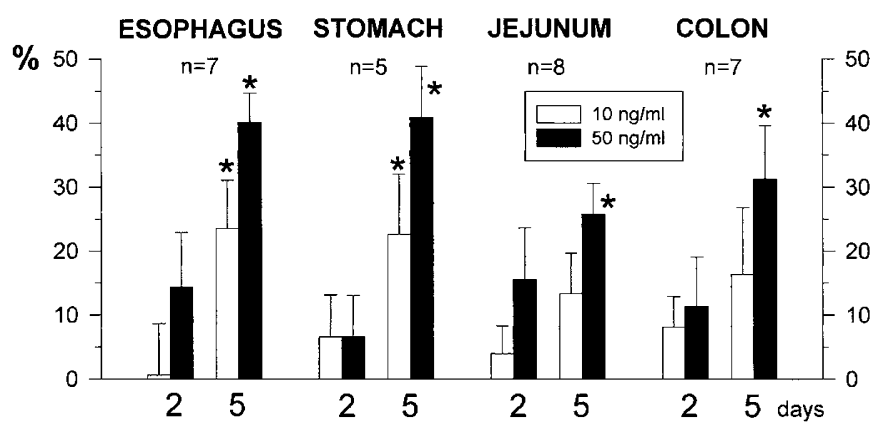

Figure 3. Effects of KGF (10 and $50 \mathrm{ng} / \mathrm{mL}$ ) on ${ }^{3} \mathrm{H}$-thymidine incorporation rates after 2 and $5 \mathrm{~d}$ of culture in explants of GI segments. Data are expressed in relative stimulation (in percentages) vs control. $\star$ indicates a significant difference $(p<0.05, t$ test) between control and KGF; $n$, the number of separate cultures done.

verified herein and in reference studies $(19,23)$, the activities of some brush-border hydrolases in jejunum are already comparable at this stage to adult levels. For SI, between 20 and 30 $\mathrm{IU} / \mathrm{g}$ protein were measured (70 to $100 \%$ of values in mature intestine), whereas only 1.5 to $2 \mathrm{IU} / \mathrm{g}$ protein were measured for lactase (30\% of newborn level). An interesting observation is that the effects of KGF were already maximal after $2 \mathrm{~d}$ of

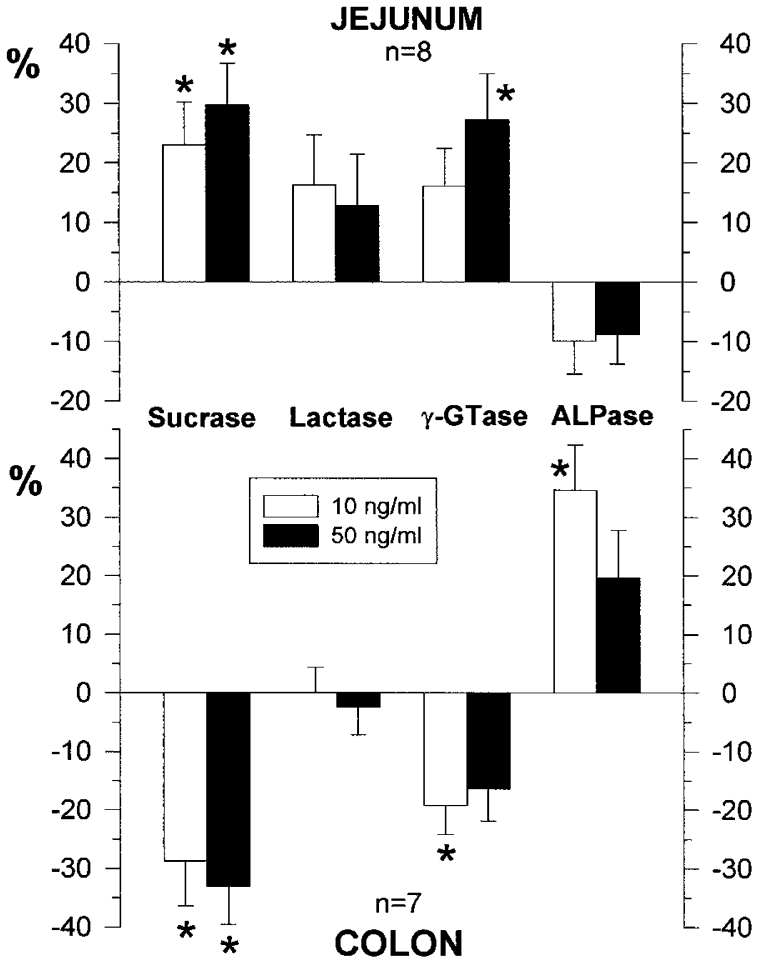

Figure 4. Effects of KGF (10 and $50 \mathrm{ng} / \mathrm{mL}$ ) on brush-border enzymespecific activities after $2 \mathrm{~d}$ of culture in explants of fetal jejunum and colon. Data are expressed in relative stimulation or inhibition (in percentages) vs control. Sucrase, $\gamma$-Gtase, and ALPase were differentially modulated in jejunum and colon. $\star$ indicates a significant difference $(p<0.05, t$ test $)$ between control and $\mathrm{KGF} ; n$, the number of separate cultures done.

culture. In jejunal explants (Fig. 4, upper panel), SI and $\gamma$-GTase activities exhibited significant 30 and $27 \%$ increases in the presence of $50 \mathrm{ng} / \mathrm{mL} \mathrm{KGF}$. On the contrary, SI and $\gamma$-GTase activity levels were decreased by 33 and $19 \%$ in colonic explants treated with the growth factor (Fig. 4, lower panel). In both segments, lactase activity remained low in the presence of KGF. ALPase activity was differently altered in the presence of $50 \mathrm{ng} / \mathrm{mL} \mathrm{KGF}$; it was unchanged in small intestine and was significantly increased by $34 \%$ in colon. The effects of HGF on brush-border enzymes were also tested on jejunum and colon after the same interval for comparative purposes (Fig. 5). When added at three different concentrations $(3,10,20 \mathrm{ng} / \mathrm{mL})$, no significant modulation of enzymic activity was induced (results for $10 \mathrm{ng} / \mathrm{mL}$ HGF are shown). In summary, it appears that KGF exerts specific and opposite effects on brush-border hydrolase activities in intestinal and colonic tissues.

\section{DISCUSSION}

The current investigation establishes that KGF and its associated receptor are present in all human fetal GI segments. In recent years, several investigators have indeed proposed that EGF-related factors (32), HGF (33-35), and KGF (36) are important and cooperative regulators of cell proliferation in developing gut tissues. They simultaneously demonstrated that KGF and HGF mRNA are synthesized by the mesenchyme/ stroma underlying the digestive epithelium and that their cog- 


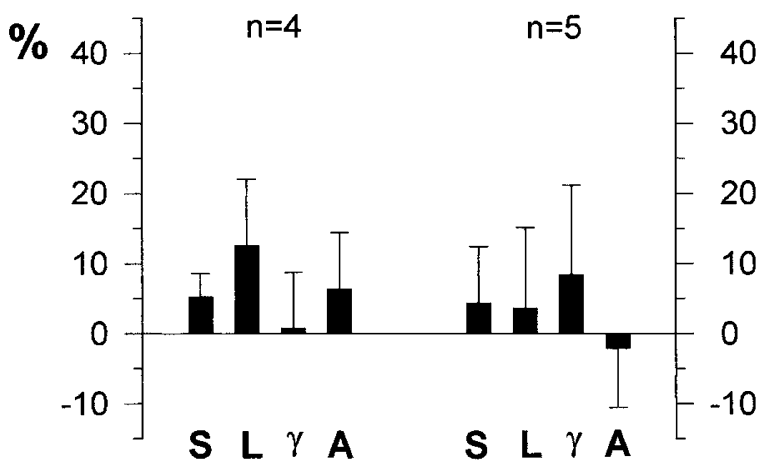

Figure 5. Effects of HGF $(10 \mathrm{ng} / \mathrm{mL})$ on brush-border enzyme-specific activities after $2 \mathrm{~d}$ of culture in fetal jejunum (left) and colon (right). Data are expressed in relative stimulation or inhibition $v s$ control. No significant stimulation or inhibition was observed in the presence of HGF. $S$ indicates sucrase; $L$, lactase; $\gamma, \gamma$-GTase; $A$, ALPase; $n$, the number of separate cultures done.

nate receptors are expressed mostly if not exclusively by epithelial cells, thus suggesting that they mediate paracrine epitheliomesenchymal interactions [reviewed by Podolsky (37)]. Of interest, researchers still await the discovery of growth factors involved in segment-specific regulation of epithelial differentiation. Our results indicate that KGF may represent a key component of this complex developmental program because it stimulates epithelial cell proliferation in vitro and differentially modulates brush-border hydrolase activities in small intestine and colon.

We revealed the ubiquitous presence of immunoreactive KGF ligand detected as a $26-28-\mathrm{kD}$ doublet in esophagus, stomach, small intestine, and colon. This doublet corresponds to KGF purified from the culture media of human cells and likely reflects differences in glycosylation patterns $(9,38,39)$. The receptors were also identified by Western blot by using anti-bek and anti-K-sam antibodies that, respectively, recognize both products (135-145 kD) of the FGFR-2/bek gene and the low molecular-weight form. As recently reported for the small intestine (36), these antibodies revealed a major $135-\mathrm{kD}$ protein in each segment, indicating that it represents the main form expressed in human fetal GI tract. In the mouse fetus, comparison of bek and KGF-R mRNA expressions similarly established that the second transcript was preferentially expressed in intestinal and gastric epithelia (8). The immunofluorescence staining data obtained on tissue cryosections illustrate that KGF-R is ubiquitously expressed in the epithelium of every GI segment, thus corroborating the identification of KGF as a paracrine epithelial growth factor in the human model. Receptors were found in proliferative cells, and this population was most intensely stained in esophagus followed by stomach, colon, and small intestine in decreasing order of intensity. Anti-KGF-R immunoreactivity was not only visualized at the basolateral membrane level but also in the cytoplasm of differentiated epithelial cells in the small intestine and colon as well as in stomach in which the cytoplasmic and nuclear compartments were most intensely labeled. Another study (6) demonstrated that proteins recognized by anti-K-sam are present on the plasma membrane and into the cytoplasm of adult gastric epithelial cells and gastric carcinoma cells. This unusual localization for growth factor receptors, which are classically associated with plasma membrane, is a feature characteristic of the FGF-R family $(1,40)$. On a functional basis, KGF binding appears to elicit phosphorylation of the membrane receptor and signal transduction with kinetics similar to other membrane receptors (41). Furthermore, it has been proposed that internalization of KGF-R, which seems rather intense in many cell types studied so far, may account for cytoplasmic immunoreactivity and important intracellular trafficking of ligand produced in the cell environment (42). It even appears that KGF-R reaching the endosomes after $10 \mathrm{~min}$ of internalization are still activated because antiphosphotyrosine signals colocalize to endosomes and putative KGF-R substrates redistributed to the same organelles are phosphorylated (42). Therefore, the localization of KGF-R at either the basolateral membrane or into the cytoplasm of fully differentiated cells suggests that KGF could also play a role as a modulator of digestive functions in the gut epithelium.

Results from organ culture experiments do provide direct evidence for the involvement of this paracrine system in the regulation of cell proliferation in the entire human fetal gut. Exogenous recombinant KGF greatly stimulated the incorporation of ${ }^{3} \mathrm{H}$-thymidine into DNA-synthesizing cells in the esophagus, stomach, and colon and to a lesser degree in the jejunum in accordance with immunofluorescence data showing varying levels of KGF-R expression in different proliferative populations. These new findings point to an important role for KGF as a regulator of cell renewal, and the observation that its stimulatory effect occurs between 2 and $5 \mathrm{~d}$ of culture further suggests that its growth-promoting action may be indirect and mediated through the release of an endogenous secondary signal. Future investigations will evaluate the possible implication of autocrine factors such as TGF $\alpha$ based upon the recent finding that this growth factor mediates the effect of KGF on the release of inflammatory cytokines in intestinal tissue (36).

The human small intestine acquires its adult morphology and most of its digestive functions very early during fetal development $(19,20)$. It is generally agreed that by $14 \mathrm{wk}$ of gestation, the overall morphologic appearance of the small intestine and the SI activity levels, for example, are comparable to those in adult intestine. We report herein that the addition of KGF to jejunal explants stimulated SI and $\gamma$-GTase without affecting lactase and ALPase. It is, thus, the first growth factor able to up-regulate human intestinal SI activity because EGF negatively influences this brush-border enzyme (43) and hydrocortisone (19) or insulin (44) remains without effect. The up-regulation of SI activity induced by KGF contrasts with the recent report that the same growth factor diminishes expression of the SI gene in Caco-2 cells (41). In the latter study, the authors concluded that KGF is able to specifically downregulate intestine-specific SI expression. One has to keep in mind, however, that this cell line was initially established from a colonic adenocarcinoma (45), and there are several indications that the closest analogy that can be found is with the human fetal colon epithelium $(46,47)$. Indeed, in the human, the colon develops between 14 and $30 \mathrm{wk}$ of gestation and is characterized by the presence of villi lined by columnar epithelial cells exhibiting all intestinal brush-border enzymes 
including SI. Between $30 \mathrm{wk}$ of gestation and birth, the villi structures will disappear along with most of the enzymic activities, whereas these will continue to be fully maintained in the small intestinal enterocytes (47). The present data clearly establish that KGF down-regulates the expression of SI in human fetal colon and, therefore, are in agreement with the KGF effects reported in Caco-2 cells (41). Further work will be required to delineate the molecular mechanisms involved in the opposite effects of KGF on brush-border enzyme activities in general and on SI in particular in the human small intestine and colon. HGF, another paracrine growth factor, and its receptor c-met have also been shown to be present in all human fetal digestive tract segments (34). The possible implication of HGF was tested in identical conditions in the small intestine and colon. As opposed to KGF, HGF did not significantly affect any of the studied enzymic activities in both segments. So even though present, HGF would not be part of the regulatory mechanisms of human brush-border hydrolase activities.

In conclusion, the KGF system likely participates in postinductive developmental processes mediated by mesenchymeepithelium interactions that control the proliferation and maturation of epithelial tissue along the entire human digestive tract. Such an assumption is based upon 1) the previous demonstration of reciprocal expression of these genes in gut stroma and epithelium, 2) the presence of immunoreactive KGF and KGF-R proteins in the mucosae of esophagus, stomach, small intestine, and colon during the second trimester of gestation when epithelial cells already possess some adult-type features and functions, particularly the small intestinal enterocytes, 3) the current observation that in each segment maintained in organ culture, exogenous KGF stimulates the proliferation of epithelial cells expressing KGF-R, and 4) the demonstration of a differential regulatory effect on brushborder SI in small intestine and colon that is consistent with the presence of receptors on differentiated cells and with their respective terminal differentiation programs. Overall, the expression pattern, as well as the suggested role of KGF (FGF-7) signaling components during the maturation of human fetal gut, clearly differs from the more localized expression of FGF-1,-2, and -8 in cardiac mesoderm and their restricted roles in morphologic outgrowth of hepatic endoderm and early induction of liver gene expression program in the five- to eight-somite mouse embryo (48). Finally, our data support the new concept that the KGF paracrine system plays a dual regulatory role on cell proliferation and digestive functions during the development and/or maintenance of the human GI tract.

Acknowledgments. The authors thank Drs C. Poulin and F. Jacot of the Département de la Santé Communautaire for their helpful collaboration in providing tissue specimens.

\section{REFERENCES}

1. Baird A, Klagsbrun M 1991 The fibroblast growth factor family. Ann NY Acad Sci 638:1-77

2. Marchese C, Rubin J, Ron D, Faggioni A, Torrisi MR, Messina A, Frati L, Aaronson SA 1990 Human keratinocyte growth factor activity on proliferation and differentiation of human keratinocytes: differentiation response distinguishes KGF from EGF family. J Cell Physiol 144:326-332
3. Wilson SE, He YG, Weng J, Zieske JD, Jester JV, Schultz GS 1994 Effect of epidermal growth factor, hepatocyte growth factor, and keratinocyte growth factor on proliferation, motility, and differentiation of human corneal epithelial cells. Exp Eye Res 59:665-678

4. Peehl DM, Wong ST, Rubin JS $1996 \mathrm{KGF}$ and EGF differentially regulate the phenotype of prostatic epithelial cells. Growth Regul 6:22-31

5. Hattori Y, Odagiri H, Nakatani H, Miyagawa K, Naito K, Sakamoto H, Katoh O, Yoshida T, Sugimura T, Terada M $1990 \mathrm{~K}$-sam, an amplified gene in stomach cancer, is a member of the heparin-binding growth factor receptor genes. Proc Natl Acad Sci USA 87:5983-5987

6. Hattori Y, Itoh H, Shinya U, Hosokawa K, Ochiai A, Ino Y, Ishii H, Sakamoto H, Yamaguchi N, Yanagihara K, Hirohashi S, Sugimura T, Terada M 1996 Immunohistochemical detection of K-sam protein in stomach cancer. Clin Cancer Res 2:1371-1381

7. Ishii H, Hattori Y, Itoh H, Kishi T, Yoshida T, Sakamoto H, Oh H, Yoshida S, Sugimura T, Terada M 1994 Preferential expression of the third immunoglobulin-like domain of K-sam product provides keratinocyte growth factor-dependent growth in carcinoma cell lines. Cancer Res 54:518-522

8. Orr-Urtreger A, Bedford MT, Burakova T, Arman E, Zimmer Y, Yayon A, Givol D, Lonai P 1993 Developmental localization of the splicing alternatives of fibroblast growth factor receptor-2 (FGFR2). Devel Biol 158:475-486

9. Finch PW, Rubin JS, Miki T, Ron D, Aaronson SA 1989 Human KGF is FGF-related with properties of a paracrine effector of epithelial cell growth. Science 245:752-755

10. Rubin JS, Osada H, Finch PW, Taylor WG, Rudikoff S, Aaronson SA 1989 Purification and characterization of a newly identified growth factor specific for epithelial cells. Proc Natl Acad Sci USA 86:802-806

11. Housley RM, Morris CF, Boyle W, Ring B, Biltz R, Tarpley JE, Aukerman SL, Devine PL, Whitehead RH, Pierce GF 1994 Keratinocyte growth factor induces proliferation of hepatocytes and epithelial cells throughout the rat gastrointestinal tract. J Clin Invest 94:1764-1777

12. Matsubara Y, Ichinose M, Tatematsu M, Ichinose M, Oka M, Yahagi N, Kurokawa K, Kageyama T, Miki K, Fukamachi H 1996 Stage-specific elevated expression of the genes for hepatocyte growth factor, keratinocyte growth factor, and their receptors during the morphogenesis and differentiation of rat stomach mucosa. Biochem Biophys Res Comm 222:669-677

13. Playford RJ, Marchbank T, Mandir N, Higham A, Meeran K, Ghatei MA, Bloom SR, Goodlad RA 1998 Effects of keratinocyte growth factor (KGF) on gut growth and repair. J Pathol 184:316-322

14. Takahashi M, Ota S, Nishimura S, Ogura K, Maeda S, Toda N, Hamada E, Terano A, Omata M 1996 Keratinocyte growth factor is an endogenous stimulant of rabbit gastric epithelial cell proliferation and migration in primary culture. J Gastroenterol Hepatol 11:1089-1096

15. Nonogaki K, Pan XM, Moser AH, Staprans I, Feingold KR, Grunfeld C 1995 Keratinocyte growth factor increases fatty acid mobilization and hepatic triglyceride secretion in rats. Endocrinology 136:4278-4284

16. Finch PW, Pricolo V, Wu A, Finkelstein SD 1996 Increased expression of keratinocyte growth factor messenger RNA associated with inflammatory bowel disease. Gastroenterology 110:441-451

17. Brauchle M, Madlener M, Wagner AD, Angermeyer K, Lauer U, Hofschneider PH, Gregor M, Werner S 1996 Keratinocyte growth factor is highly overexpressed in inflammatory bowel disease. Am J Pathol 149:521-529

18. Iida S, Katoh O, Tokunaga A, Terada M 1994 Expression of fibroblast growth factor gene family and its receptor gene family in the human upper gastrointestinal tract. Biochem Biophys Res Comm 199:1113-1119

19. Ménard D 1989 Growth-promoting factors and the development of the human gut. In: Lebenthal E (ed) Human Gastrointestinal Development. Raven Press, New York, pp 123-149

20. Montgomery RK, Mulberg AE, Grand RJ 1999 Development of the human gastrointestinal tract: twenty years of progress. Gastroenterology 116:702-731

21. Ménard D, Arsenault P 1987 Maturation of human fetal esophagus maintained in organ culture. Anat Rec 217:348-354

22. Ménard D, Arsenault P, Monfils S 1993 Maturation of human fetal stomach in organ culture. Gastroenterology 104:492-501

23. Ménard D, Arsenault P 1985 Explant culture of human small intestine. Gastroenterology 88:691-700

24. Ménard D, Arsenault P 1987 Human fetal colon in organ culture. Anat Embryol 176:441-448

25. Streeter GL 1920 Weight, sitting head, head size, foot length, and menstrual age of the human embryo. Contr Embryol 11:143-179

26. Giles KW, Myers A 1965 An improved diphenylamine method for the estimation of deoxyribonucleic acid. Nature 206:93-94

27. Lloyd S, Whelan W 1969 An improved method for enzymic determinations of glucose in the presence of maltose. Anal Biochem 30:467-470

28. Eichholz A 1976 Structural and functional organization of the brush border of intestinal epithelial cells. III. Enzyme activities and chemical composition of various fractions of Tris-disrupted brush borders. Biochim Biophys Acta 135:475-482

29. Naftalin L, Sexton M, Whitaker JF, Tracey D 1969 A routine procedure for estimating serum $\gamma$-glutamyl transpeptidase activity. Clin Chim Acta 26:293-296

30. Lowry OH, Rosebrough NF, Farr AL, Randall RJ 1951 Protein measurement with the Folin phenol reagent. J Biol Chem 193:265-275

31. Tremblay E, Basque JR, Rivard N, Ménard D 1999 Epidermal growth factor and transforming growth factor $\alpha$ downregulate human gastric lipase gene expression. Gastroenterology 116:831-841

32. Chailler P, Ménard D 1999 Ontogeny of EGF receptors in the human gut. Front Biosci 4:d87-d101 
33. Wang Y, Selden C, Farnaud S, Calnan D, Hodgson HJ 1994 Hepatocyte growth factor (HGF/SF) is expressed in human epithelial cells during embryonic development; studies by in situ hybridisation and Northern blot analysis. J Anat 185:543-551

34. Kermorgant S, Walker F, Hormi K, Dessirier V, Lewin MJM, Lehy T 1997 Developmental expression and functionality of hepatocyte growth factor and c-met in human fetal digestive tissues. Gastroenterology 112:1635-1647

35. Kolatsi-Joannou M, Moore R, Winyard PJD, Woolf AS 1997 Expression of hepatocyte growth factor/scatter factor and its receptor, MET, suggests roles in human embryonic organogenesis. Pediatr Res 41:657-665

36. Bajaj-Elliott M, Poulsom R, Pender SLF, Wathen NC, MacDonald TT 1998 Interactions between stromal cell-derived keratinocyte growth factor and epithelial transforming growth factor in immune-mediated crypt cell hyperplasia. J Clin Invest 102:1473-1480

37. Podolsky DK 1994 Peptide growth factors in the gastrointestinal tract. In: Johnson LR (ed) Physiology of the Gastrointestinal Tract, 3rd Ed. Raven Press, New York, pp $129-167$

38. Finch PW, Cunha GR, Rubin JS, Wong J, Ron D 1995 Pattern of keratinocyte growth factor and keratinocyte growth factor receptor during mouse fetal development suggests a role in mediating morphogenetic mesenchymal-epithelial interactions. Dev Dyn 203:223-240

39. Brauchle M, Angermeyer K, Hübner G, Werner S 1994 Large induction of keratinocyte growth factor expression by serum growth factors and pro-inflammatory cytokines in cultured fibroblasts. Oncogene 9:3199-3204
40. Hughes SE 1997 Differential expression of the fibroblast growth factor receptor (FGFR) multigene family in normal human adult tissues. J Histochem Cytochem 45:1005-1019

41. Zhou J, Wu K, Fernandes CL, Cheng AL, Finch PW 1998 Keratinocyte growth factor down-regulates expression of sucrase-isomaltase gene in Caco-2 intestinal epithelial cells. J Biol Chem 273:33367-33373

42. Marchese C, Mancini P, Belleudi F, Felici A, Gradini R, Sansolini T, Frati L, Torrisi MR 1998 Receptor-mediated endocytosis of keratinocyte growth factor. J Cell Sci 111:3517-3527

43. Ménard D, Arsenault P, Pothier P 1988 Biologic effects of epidermal growth factor in human fetal jejunum. Gastroenterology 94:656-663

44. Ménard D, Corriveau L, Beaulieu JF 1999 Insulin modulates cellular proliferation in developing human jejunum and colon. Biol Neonate 75:143-15

45. Fogh J, Fogh JM, Orfeo T 1977 One hundred and twenty-seven cultured human tumor cell lines produced tumors in nude mice. J Natl Cancer Inst 59:221-226

46. Rousset M 1986 The human colon carcinoma cell lines HT-29 and Caco-2: two in vitro models for the study of intestinal differentiation. Biochimie 68:1035-1040

47. Ménard D, Beaulieu JF 1994 Human intestinal brush border membrane hydrolases. In: Bkaily G (ed) Membrane Physiopathology. Kluwer Academic Press, Boston, pp 319-341

48. Jung J, Zheng M, Goldfarb M, Zaret KS 1999 Initiation of mammalian liver development from endoderm by fibroblast growth factors. Science 284:1998-2003 